\title{
The role of non-scholar organisations in environmental education: a case study from Portugal
}

\section{Luisa Schmidt and João Guerra*}

ICS/UL - Social Sciences Institute of University of Lisbon, Av. Professor Anibal de Bettencourt, 9 - 1600 Lisboa, Portugal Fax: 351217940274

E-mail: schmidt@ics.ul.pt

E-mail: Joao.Guerra@ics.ul.pt

*Corresponding author

\section{Joaquim Gil Nave}

ISCTE - Institute of Social Sciences and Business Studies, Av. Das Forças Armadas, Edificio ISCTE, 1649 Lisboa, Portugal Fax: 351217964710

E-mail: Joaquim.Nave@iscte.pt

\begin{abstract}
The aim of this study was to identify, characterise, collect and systematise data on initiatives of environmental education in Portugal. Currently, there is no integrated governmental program on environmental education in this country, but only unrelated voluntary initiatives. Although surveys indicated a growing concern by young people on environmental issues, systematic studying on the issue was lacking. The field seemed to be characterised by wide diversity and disperse voluntary action by non-governmental agents and self-mobilised teachers. In the context of the Decade Dedicated to Education for Sustainable Development of UNESCO, governmental and non-governmental organisations dedicated to the environment now have a new opportunity to enhance and coordinate contributions to make environmental issues a priority for the next generation.
\end{abstract}

Keywords: environmental education; EE; Portugal; non-scholar organisations; education for sustainable development; ESD.

Reference to this paper should be made as follows: Schmidt, L., Guerra, J. and Nave, J.G. (2010) 'The role of non-scholar organisations in environmental education: a case study from Portugal', Int. J. Environment and Sustainable Development, Vol. 9, Nos. 1/2/3, pp.16-29.

Biographical notes: Luisa Schmidt is a Sociologist and Senior Researcher at the Institute of Social Sciences, University of Lisbon. She works on Sociology of the Media and Environmental Sociology. Since its foundation in 1995, she has co-led OBSERVA, a research programme on environment, society and public opinion. She is also a member of the National Council for the Environment, an independent agency of the administration in charge of monitoring environmental policy initiatives and legislation.

João Guerra is a Sociologist and Researcher in OBSERVA and Institute of Social Sciences, University of Lisbon (ICS-UL). Since 1998, he has participated in several research projects including studies on Portuguese environmental values, sustainability, civic participation and governance, environmental education, etc. 
Joaquim Gil Nave is a Sociologist and Senior Professor at the Instituto Superior de Ciências do Trabalho e da Empresa - ISCTE (University Institute of Social Sciences and Business Studies). He runs courses on environmental sociology and has co-directed the OBSERVA - Observatório Permanente de Ambiente, Sociedade e Opinião Pública (a research programme on environment, society and public opinion) since its foundation in 1995.

\section{Introduction}

Once the domain of governmental and non-governmental organisations involved in social mobilisation and environmental issues, environmental education (EE) has gained in importance in educational systems. EE has progressively opened up to include educational activity such as citizenship and healthcare. At the same time, the urgency and permanence of environmental problems in contemporary societies and their connections with particular scientific areas, such as the more obvious case of nature sciences, has assured them an undisputed place in basic educational formation of citizens in modern societies, if nothing else a set of proposed pedagogies based on experimental observation or playing while learning. Likewise, while the environment has come to be a specific sector of collective and public action, as well as a sphere of state administration, environmental issues must include economy and other socio-political equilibriums as well as sustainability. Hence, there is a need for education for sustainable development (ESD).

EE has gradually emerged from the logics of propagandistic essentialism of early environmental activism to impose itself as an undeniable formative and civic dimension of modern education where it reaches a new status and social significance. However, it seems that there is still the need for initiatives, mobilisation and intervention of non-scholar actors in EE or in ESD.

The main aim of this paper is to characterise and assess the role of non-scholar organisations, governmental and non-governmental, private and public, in EE in Portugal. This bears in mind the subtle movement for change that is emerging, both in the sense of a greater intensification of the school system's role in the EE of citizens and in the sense of a greater articulation, if not fusion, with other areas of education for citizenship. The analysis is based on a systematic survey applied to non-scholar organisations that run EE initiatives outside the formal educational system, though often in collaboration with schools. An analytical characterisation of the contribution of these organisations to EE (or ESD) in the case study country is presented addressing in particular the trends of changes, while looking also to difficulties and assertiveness strategies of these organisations in this field of social action. Since it is crucial to perspectives on EE discussed in this paper, we will spotlight the analysis of formative and educational activities with respect to the conceptions about citizenship.

\section{From environmental education to learning for sustainable development}

The concept of EE emerged during the 60 s with the growing evidence of environmental degradation and non-sustainable consumption of natural resources and of its connections 
to the growing ability of techno-scientific advancements that interfere with nature and ecological systems.

Nowadays, awareness on issues such as the depletion of the ozone layer, global warming, contamination of water, air pollution, devastation of forests, destruction of natural habitats and the consequent reduction in biodiversity, has reached new levels of concern. In order to overcome them, there is an urgent need for profound changes in attitudes and behaviours so as to support a more responsible management of resources and a true social equity. This means more justice in availability and use of natural resources, not only for nations and social groups, but also for different generations.

Actually, EE opened a distinct area in the formation and education of citizens, in a process aimed at making individuals gain awareness of their environment and acquire knowledge, skills, values, experiences, motivations and commitments to make informed decisions and take responsible action about it. EE was aimed at producing a citizenry that has to be knowledgeable concerning the biophysical environment and its associated problems, knowing how to help solve these problems and motivated to work towards their solution (Stapp et al., 1969). In this sense, EE was thought to be a progressive and dynamic process in order to achieve the goals highlighted in Tbilisi Declaration (UNESCO, 1978):

- to foster clear awareness of and concern about, economic, social, political and ecological interdependence in urban and rural areas

- to provide every person with opportunities to acquire the knowledge, values, attitudes, commitment and skills needed to protect and improve the environment

- to create new patterns of behaviour of individuals, groups and society as a whole towards the environment.

However, ecological imbalance and environmental degradation are, at least in part, a consequence of diverse and maladjusted consumerism conditions of modernity, as well as of poverty and endemic inequalities that still plague most of the world population. Hence, a balanced and sustained ecological development requires, according to the Bruntland report, that satisfaction be given to the basic needs of everyone and everyone may have the possibility of satisfying their aspirations to a better life (WCED, 1991).

Departing from the original idea of sustainable development, ESD is now arising in conjunction with the UNESCO initiatives for a Decade of Education for Sustainable Development. ESD includes all principles of EE itself, but it aims to go further in that it promotes directly change in peoples living in order to altering behaviour to achieve sustainable living, i.e., living in a way that seeks to avoid depletion of non-renewable resources which future generations will also need. It acknowledges that people are not only the problem, but are also the solution to many environmental troubles, while recognising that people's behaviour have impact on economic, political, social and cultural fields, thus, that people have a big part to play in sustainable living.

However,

"while on first appearances, ESD appears to be more holistic with its explicit embrace of the social, economic and intergenerational dimensions, in practice EE has become more radical in its social critique and holistic philosophy. On the other hand, ESD is receiving much more funding and greater acceptance which is interconnected with the concept of ESD becoming mainstreamed, implicitly embracing economic growth and rarely questioning of structural issues of social inequality." [Binstock, (2006), p.3] 
The excessive stress on issues of development, which too often means economic growth, led some authors to be very critical on sustainable development and especially on practical results. In this sense, EE would serve better the declared objectives of both (EE and ESD), because, from this point of view, it is less connected to a world status quo which, in the name of the sustainable development idea, still remains predatory and ignores the real issues of sustainability: an holistic view that underlines the potential longevity of vital human ecological support systems, such as the planet's climatic system, systems of agriculture, industry, forestry, fisheries and the systems on which they depend (Boff, 2004).

Nevertheless, as Jickling and Spork (1998) noted, the creation and adoption of a promising new environmental vision should be viewed not as an aim of education, but as one of the logical and practical outcomes of an educational process. This is why our perspective recommends that both denominations have to meet the most important dimensions which must be fulfilled by education in view of enhancing environmental performances of modern societies. These include civic education to promote participation and the will to achieve balance both in relationships between society and the environment and between different human communities, rich and poor, developed and developing ones. After all, the balance of the first pair depends also on the balance between the latter.

This particularly applies to the Portuguese case, whose development shows some particularities within the European context. This country went straight from an impoverished rural society to a modernised culture. Thereby, it still performs important deficits in social benefits and economic patterns current in advanced developed world. This ended up creating a special sensitivity to social and economic issues in society (Schmidt, 2005; Schmidt et al., 2006).

In Portugal, EE arose about 30 years ago. However, only by the mid-80s did it gain formal and institutionalised patterns, entering the scholar curricula by virtue of the European influence. Notwithstanding, its impact still seems too tenuous two decades later. A study carried out in the 90s proved how EE kept showing very low performances, fundamentally due to the lack of expertise among teachers, lack of articulation within the scholar curricula and non-evaluation of educational activities (Martinho, 2003). That is, EE weak performances were not only due to the classic reasons of systematic lack of means by organisations doing it, but also to chronic institutional problems of non-articulation and lack of planning and continuity of educational activities, which adds to functional inability to cope with the galloping spread and growing of importance and scale of environmental problems in the country and around the world.

In spite of this, inquiry outputs from questionnaires applied in 1997 and 2000 to statistic representative samples of the Portuguese population, focusing on environmental values, attitudes and practices, show that very strong concerns with the environment have increased immensely among young people, while, paradoxically, the level of information, knowledge and civic participation about it was very low (Almeida, 2000, 2004). The famous EE seems to have fallen into a bottomless pit of general illiteracy (Benavente, 1996). Hence, there is urgency for systematic studies on the issue, in order to provide information on what kinds of projects, subjects and protagonists are in the field and what goals are being achieved. This will allow the case study country to make use of opportunities and to establish new perspectives and new policies.

The task is thus to evaluate from a diagnosis perspective the current situation in non-scholar institutions that promote or develop programs of EE/ESD. This may help to determine constraints and potentials and delineate lines of public action in this area. In 
the end, it is also about giving visibility to educational projects and programs, due to the initiative of either public or private institutions; environmental and developing-aid NGOs; central and local administration organisations; or companies of the environmental sector and members of sustainable networks.

To achieve these objectives, it was necessary to make use of multiple techniques and methods of research and data collection. These included documental research and collection of data in relevant governmental and non-governmental organisations (e.g., Education Ministry, Environment Ministry, local administrations, NGOs, companies and so on); interviews of experts and leaders of model cases of EE/ESD initiatives; and finally, a survey using a questionnaire applied to non-scholar promoters of EE/ESD. The questionnaire was applied for over a period of nine months (i.e., June of 2005 to February of 2006) by establishing initially more than 6,500 contacts by traditional mail, e-mail and by phone, in order to get the greatest number of responses to the questionnaire.

Organisations contacted included Portuguese municipalities and local government associations, regional departments and bodies in central administration dealing with environment, urbanism, education, security and social solidarity, all environmental NGOs for local and sustainable development; EE theme parks, zoos, 'ecotecas', 'live science' centres, organisations for young people run by religious organisations, such as parishes, scout groups and charities; universities and scientific research centres; foundations and museums; professional and union associations; business and local and national business associations and their associate organisations; and newspaper and media groups.

\section{The contribution of non-scholar organisations to environmental education}

In this article, we seek to report on the results of an inquiry applied to non-scholar institutions which allows for an analysis of the dynamics of EE/ESD in the case study country of Portugal. The non-scholar institutions sustain, manage and stimulate a good portion of the projects carried out in the country, even in schools.

The typology that was adopted at the start to approach these institutions was very ambitious and as exhaustive as possible, so that a maximum of diversity of cases could be covered. In the end, some categories were aggregated and others were eliminated.

The greatest number of ongoing projects was run by EE equipments (45\%), local administration (38.6\%) and environment NGOs (38.3\%) (Figure 1). With values still above the global average were central administration bodies and companies and business associations. Finally, with less expressive frequencies, there were institutions connected with the Catholic Church (parishes and charities), which, despite their great mobilising capability in social voluntary work, seem remote from environmental and sustainable development priorities $(0.6 \%)$. The group formed by museums, universities and foundations, which doesn't rise above $2.5 \%$ and development NGOs, with $12.4 \%$ of projects, also seemed more attuned to other causes and motivations. Local administration answered the inquiry with a greater number of projects developed per institution (2.92, with almost all municipalities having more than three projects each (Figure 2). 
The dynamics and level of effort each institution shows in the promotion of EE/ESD projects are diversified and stem, in large measure, from their own social object. Hence, environment NGOs (2.7) and equipments and theme parks related to environment issues (2.4) come first. Companies (2.09) and central administration (2.05) are the groups that come next; that position being justified, in large measure, by the reduced number of entities which answered affirmatively. In the case of central administration, it is the bodies and services with more connections to environmental themes (above all, the protected areas) that accumulate more EE/ESD activities. Traditionally less connected to environmental questions are groups of institutions like universities, museums and foundations (1.62), development NGOs (1.00) and parishes and charities (1.00).

What are the targets? As far as can be concluded by looking at Figure 3, the projects' targets are the school community, with preponderance of basic school pupils and among them, those at the elementary level with $61.8 \%$ of the answers. University students stand apart for the opposite motive: the weak investment of institutions in this kind of student, with less than $5.1 \%$ of replies. In fact, as the schooling level increases (and consequently, also age), investment of promoters on EE projects tend to diminish drastically.

Globally, however, most of the recorded projects point, on the one hand, to the exclusiveness of the school community $(87 \%)$ and, on the other hand, to the groups of younger pupils, leaving a somewhat depressing void among the non-scholar populations and among post-teen or pre-adult pupils. The latter in theory are harder to mobilise.

When the projects were analysed by declared years of duration (Figure 4), it was noticed that, in global terms, only about a third lasted more than three years (33\%). A few more dated the beginning of project from less than three years. Finally, in $30 \%$ of cases, there was no conclusive answer. However, the 'non-answers' allow us to guess that the projects are recent or, in the best hypothesis, have a structure that is not systematised enough to be able to answer.

Figure 1 Response rates by groups of entities contacted (see online version for colours)

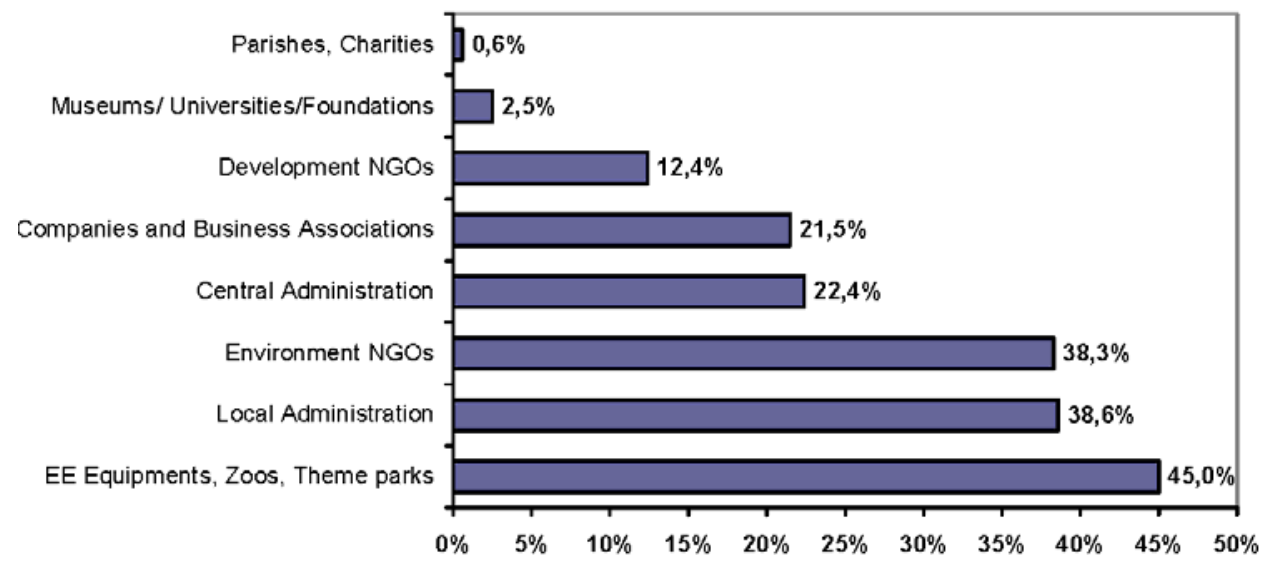


Figure 2 Projects by groups of entities (see online version for colours)

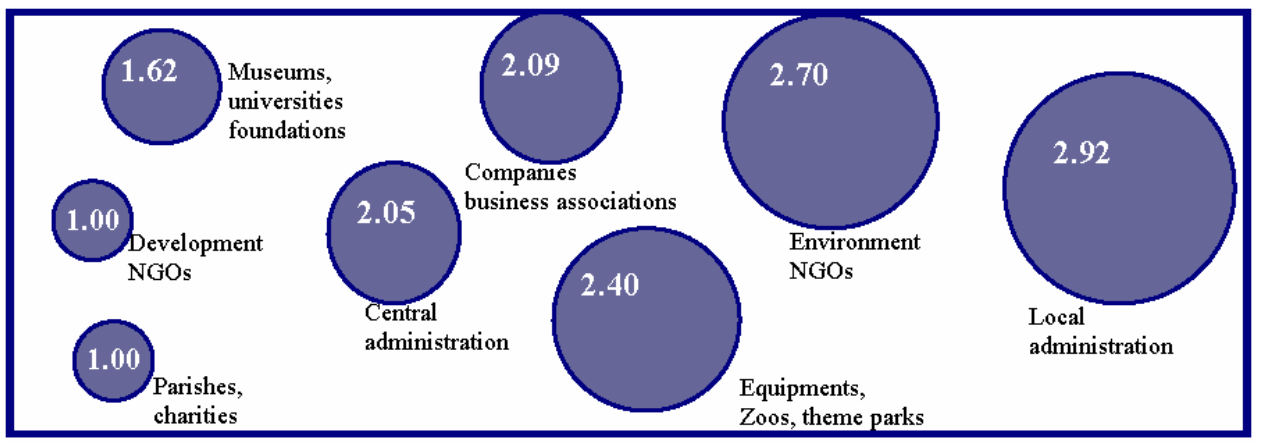

Figure 3 Projects' target groups (see online version for colours)

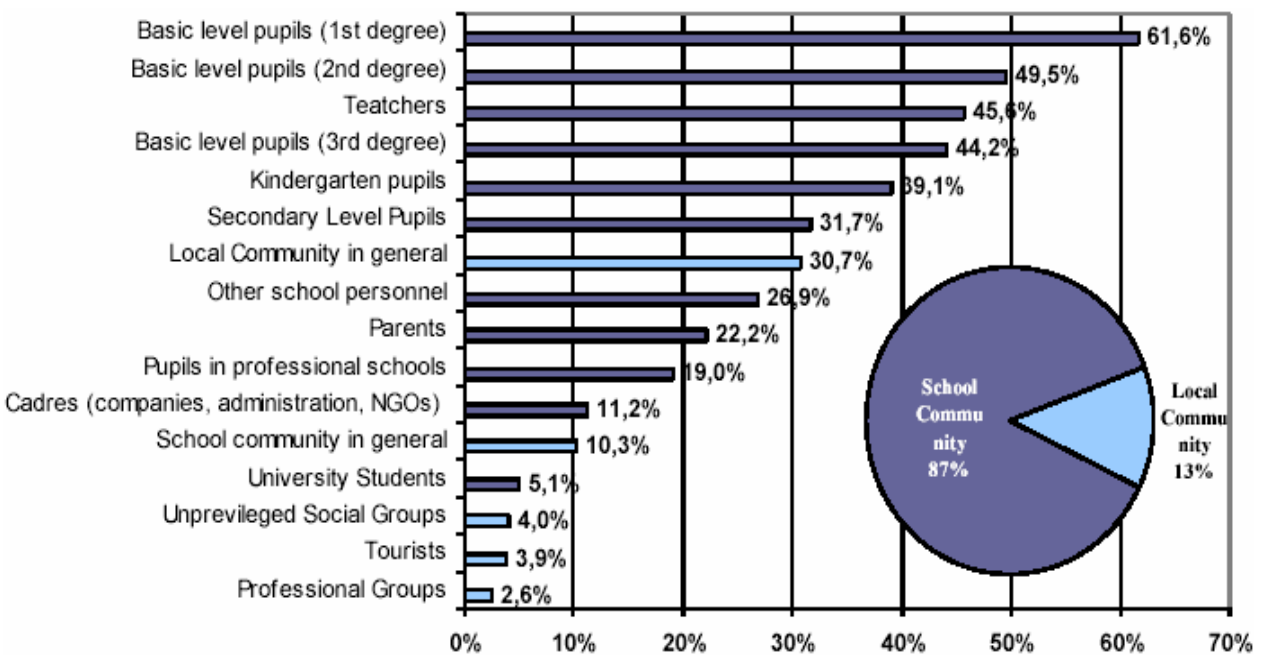

Figure 4 Project duration by kind of institution (see online version for colours)

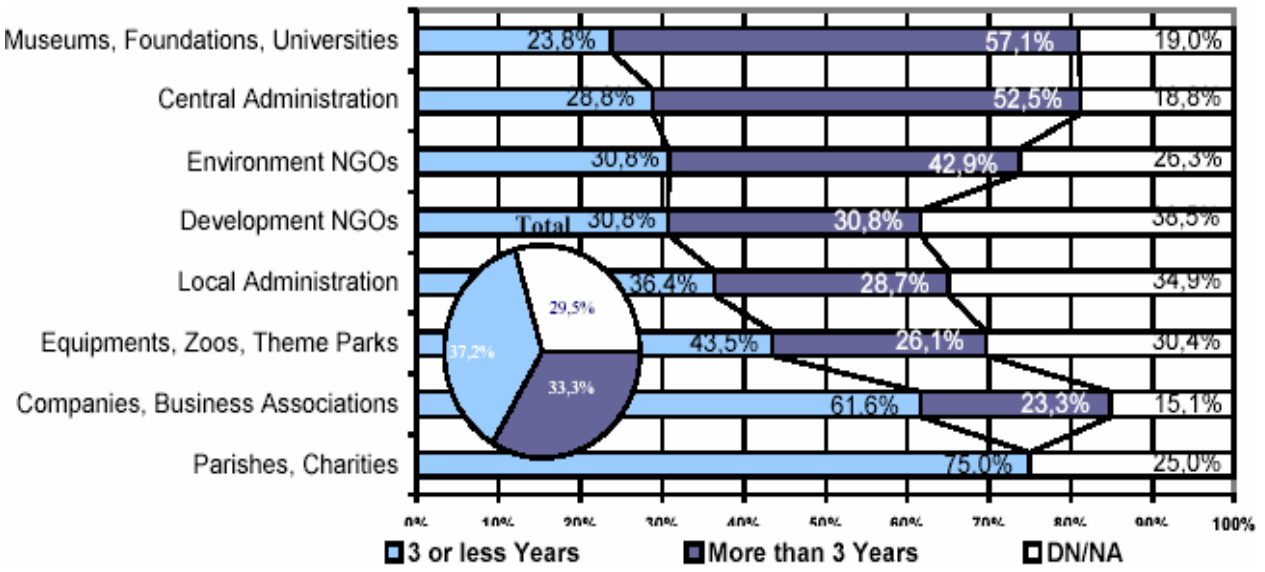


As regards the promoting institutions, it is clear that museums, foundations and universities (57.1\%), central administration (52.5\%) and environment NGOs $(42.9 \%)$ carry out the oldest projects. These tend to be more resistant to setbacks and daily constraints and, therefore, more sustainable. NGOs of development and local administration, in turn, tend to be divided between older and more recent projects, but were distinguished, above all, by the greatest rate of 'non-response' (38.5\% and $34.9 \%$, respectively).

What about the greatest difficulties found by those promoters? To mobilise participants and targets for projects to be developed or already ongoing seems to be the first great difficulty (Figure 5). Almost 30\% of answers mention this category specifically, which indicates a lack of will and interest towards issues of environment and sustainable development. This difficulty appears even more among teachers. Maybe the need to include and conquer teachers to insure the success of projects in schools justifies this value that overtakes all other groups.

Figure 5 Most frequent difficulties in development of projects (see online version for colours)

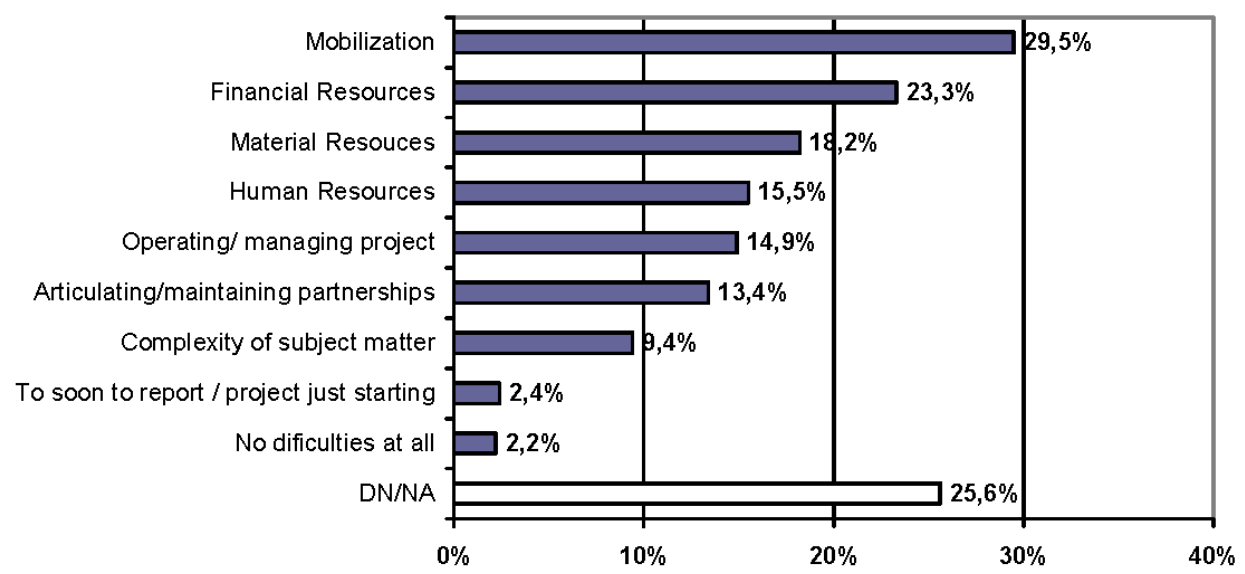

Figure 6 Most satisfying results (see online version for colours)

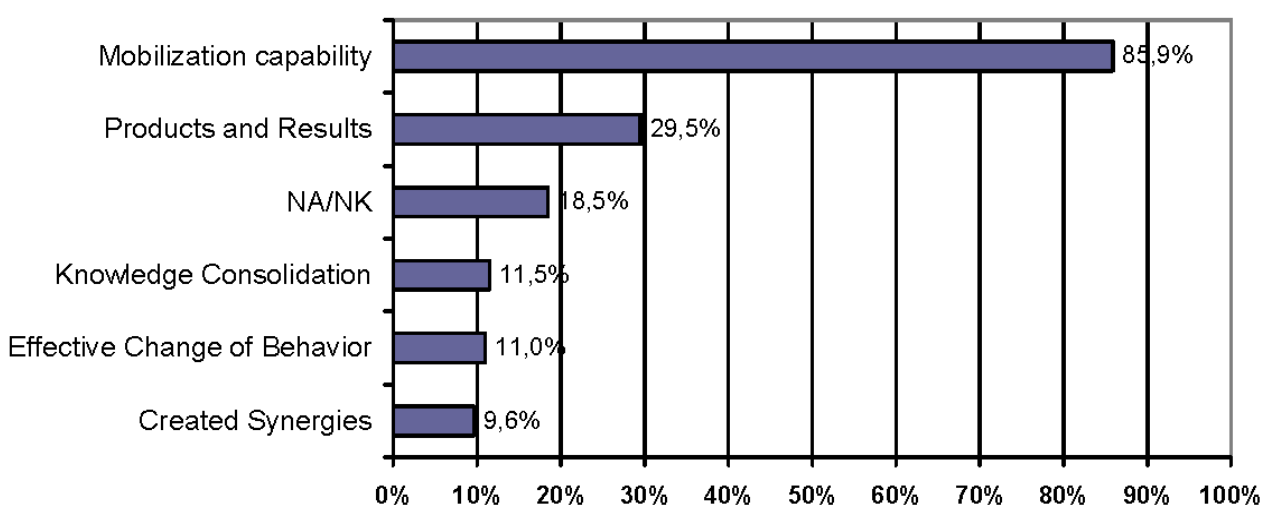


The second group of difficulties has to do with lack of resources. Financial resources in first place (23.3\%), but also availability of teaching and working materials $(18.2 \%)$ and in human resources with the adequate technical know-how to overcome daily problems $(15.5 \%)$.

The third group of problems has to do with questions of project organisation. At the head were difficulties in operating and/or managing the project (14.9\%), followed by difficulties in articulation and/or maintaining partnerships (13.4\%) and, finally, of complexity of subject matters $(9.4 \%)$.

What may be the most satisfying results? According to Figure 6, the most satisfying results reside in the mobilisation capability, especially among young men $(30.3 \%)$ and teachers $(10.5 \%)$. Apparently the successes reached in this area, however small they may be, become trophies that are instantly named.

In second place stands satisfaction with products and results of the projects, due to standards of quality achieved (11.7\%), to the number of participants $(5.5 \%)$, or to achievements in recycling and selective deposition in communities and schools (4.2\%). Effective change of behaviour and consolidation of knowledge, despite being explicit objectives in most of these projects, were not judged positively by more than $11.5 \%$ of the respondents. Finally, let us mention that for $9.6 \%$ of the respondents, the synergies created by this kind of project are evaluated positively by almost $10 \%$ of the respondents.

\section{Environmental education: from environmental problems to citizenship issues}

Beckman (2001) noted that citizens who minimise their garbage or who prefer ecological goods will often do this because they feel committed to ecological values and ends. To produce citizens that act responsibly is the biggest task of EE. What themes remain today in EE/ESD (Figure 7)? To start with, four thematic areas stand out: conservation $(45.4 \%$ of recorded projects), residues (42.6\%), water (28.2\%) and issues of citizenship (16.8\%). On a second level, there are urban environment, forests, energy, historical and cultural heritage and the environment in general. Finally, with values below $10 \%$ are thematic areas like sustainable development, agriculture, science and technology, issues of health and quality of life, the air, coastal areas and economic activities and, finally, the issue of sustainable consumerism. Since the data behind Figure 7 resulted from a preliminary treatment of answers to open questions, let us see which questions are included in some of these areas.

In the thematic group we called conservation (Figure 8), there is a wide variety of subsystems with special focus on issues of fauna and flora (34.3\%). Without other specifications, the theme of conservation in general comes next $(17 \%)$. Let us note, however, that in a country with innumerable protected areas and an area of Natura 2000 Network corresponding to $22 \%$ of the territory, very few EE/ESD projects had to do with these classified areas as specific ecosystems.

The thematic area of citizenship is another group deserving some additional reflection, since it aggregates results from an open question and whose choice forcibly implies some subjectivity. What is meant by citizenship is, above all, change of attitudes and behaviours pointed explicitly in almost half of the projects grouped in this thematic area $(47.2 \%)$. With rather less expressive values comes the question of adoption of new values and social responsibility (13\%), of actions of social integration and support 
$(12.4 \%)$, of promotion of public participation in the life of communities $(11.2 \%)$. All pressing subjects in a society that, in European terms, keeps the lowest levels of civic participation, whether organised or not, of short or long duration. Finally, with little more than residual values there are the rights of animals, of immigrants and refugees and global citizenship (Figure 9).

The thematic groups of the environment in general and sustainable development are the result from a generalised and perhaps not too rigorous application of concepts. In many cases (Figure 10) it is not possible to distinguish what problems are really at stake in the respondents answer.

The same procedure may be mentioned for the second and third categories in this thematic group: sustainable development in general $(26.2 \%)$ and EE and education towards sustainable development (20.1\%). The ambiguity and imprecision of answers did not allow for an improved clarification of themes. The slightly more concrete question and rather less frequent: pollution (14\%), artistic and/or playful work about environment $(7.3 \%)$ and, with residual weight, ecological footprint that does not go beyond $0.6 \%$ of the answers were grouped in this thematic area.

Besides the more frequent themes, we should underline some questions that deserve greater attention in the national context. In a time abundant in forest fires and long periods of drought $(16.5 \%)$, not even those connected with fires and the forest $(6.6 \%)$ have received sufficient attention. At this points to the need of acting at the most elementary pedagogical levels (Schmidt and Lima, 2005).

Outside the ranking of the more frequent subjects there were also global problems. Neither climate change, nor the destruction of the ozone layer, nor the loss of biodiversity was highlighted by the respondents. Apparently the environment is mostly treated as a local problem with local repercussions, with little connection being made with the global consequences of those problems.

Figure 7 Themes of projects (see online version for colours)

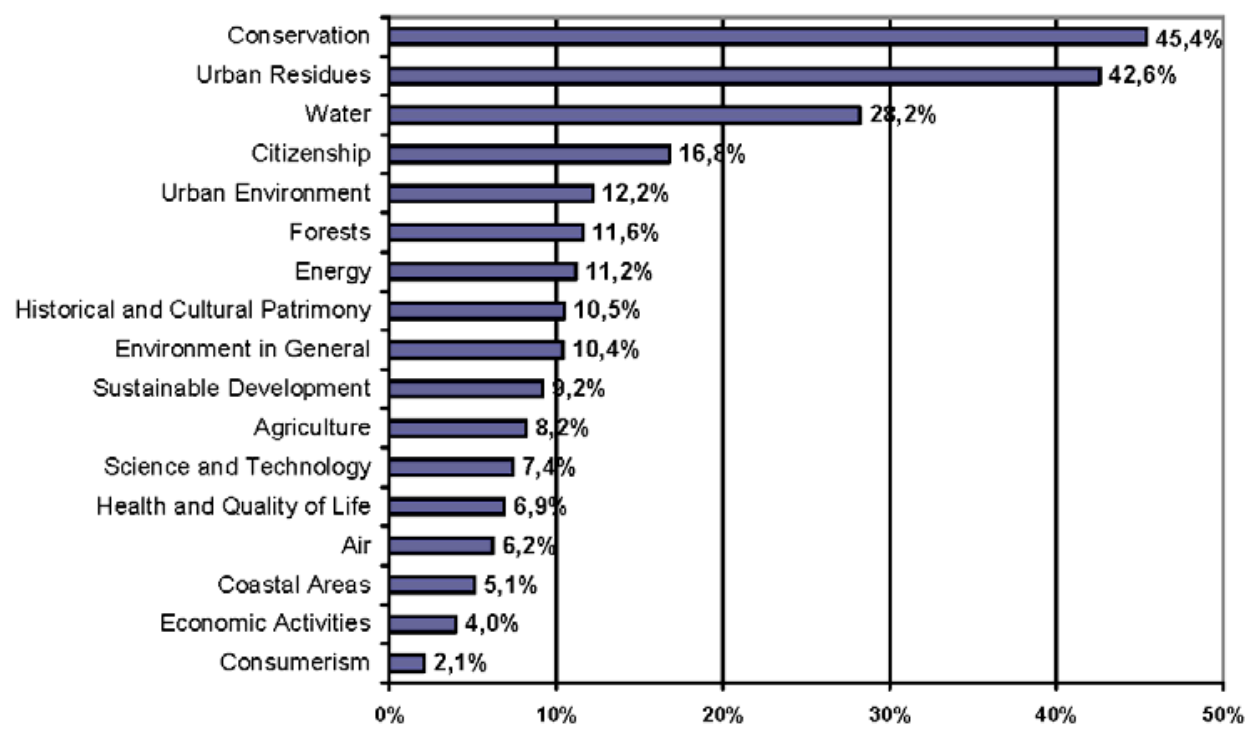


Figure 8 Questions included in thematic group 'conservation' (see online version for colours)

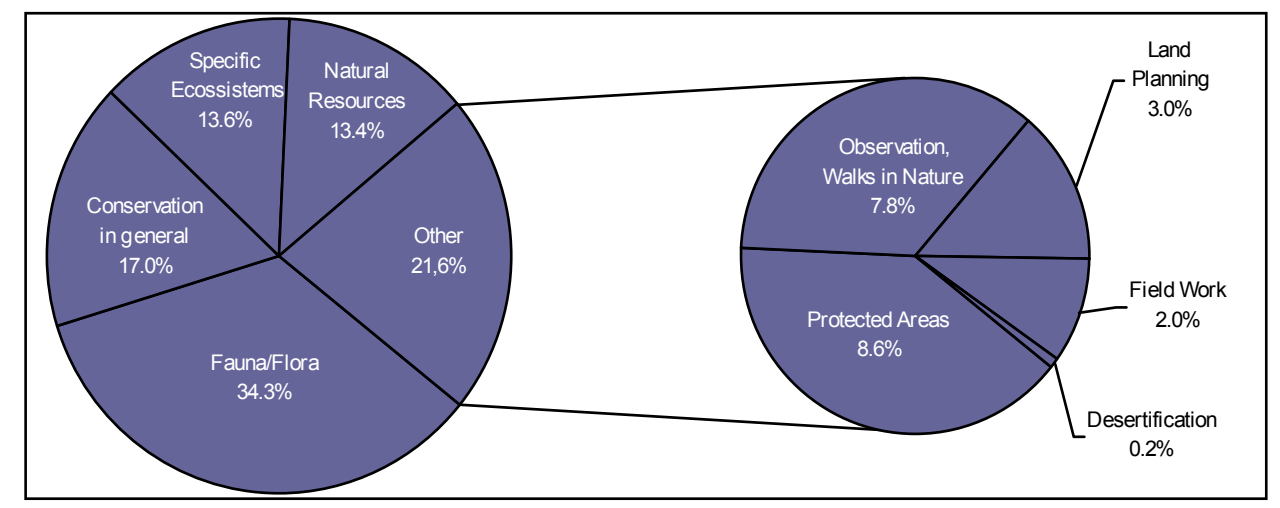

Figure 9 Questions included in thematic group 'citizenship' (see online version for colours)

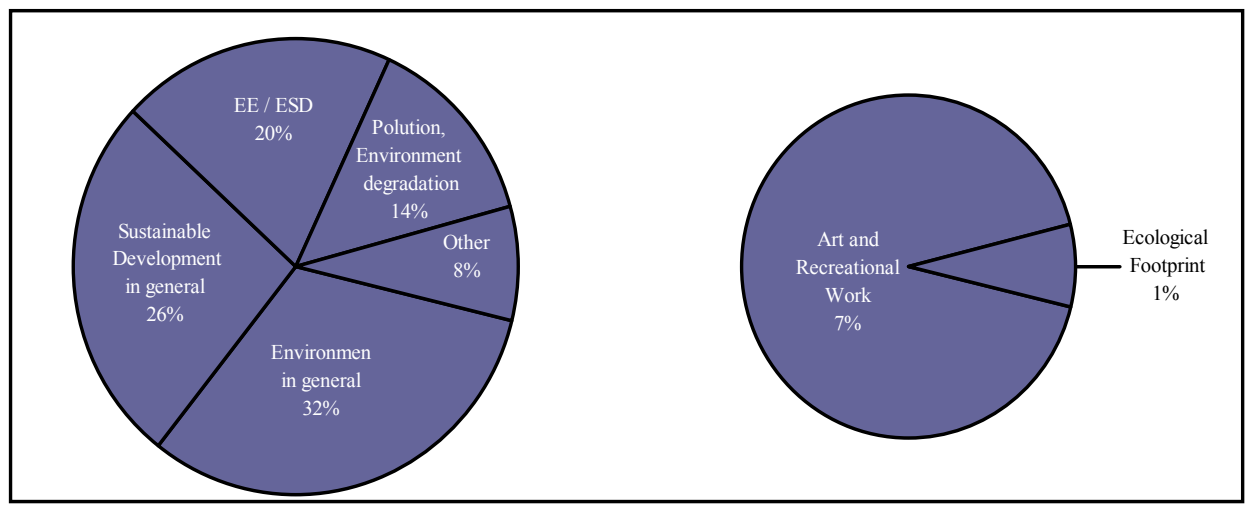

Figure 10 Questions included in thematic group 'environment and sustainable development (see online version for colours)

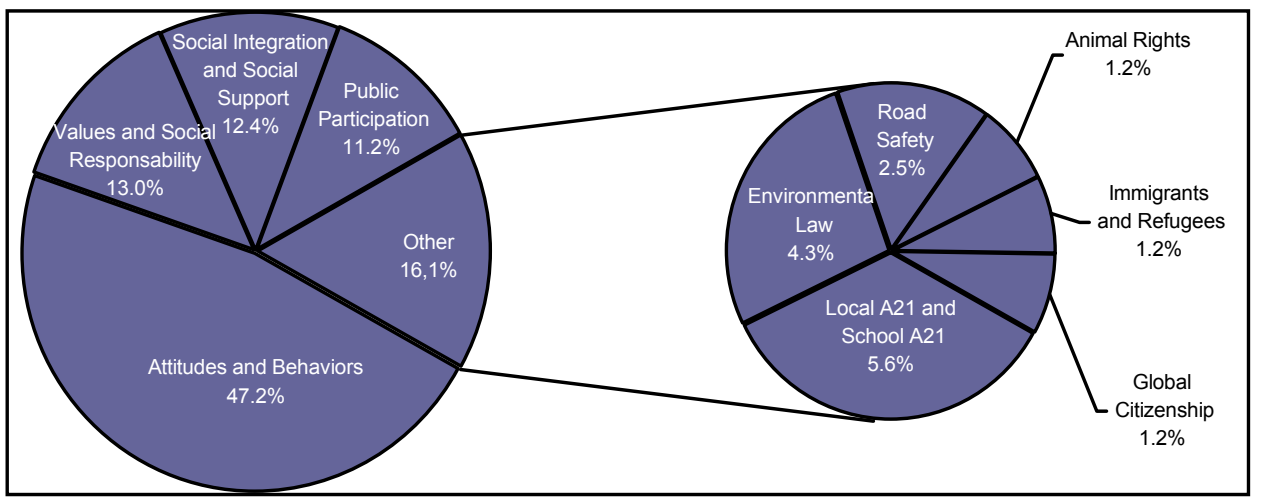




\section{Concluding remarks}

In view of these observations and commentaries, one would say that EE and ESD in Portugal is characterised as being more vertical than transversal, be it either in the sense of territory incidence or theme contents. Action is confined to scholar walls, rarely penetrating or involving the community. Though we only analysed questionnaires applied to non-scholar organisations that promote EE/ESD, non-scholar educational projects or those aiming for surrounding community do not go over $13 \%$ of the total studied. Even on projects developed inside the school, it was not very common to have the presence of transversal actions covering the entire scholar community (i.e., including students, teachers, auxiliary and administrative staff).

We perceive the predominance of a very limited and in some way traditional, set of subjects: fauna, flora and recycling. For instance, conservation of nature, which lies at the rising of the environmental movement in Portugal, some decades ago and still remains as an important anchor of action and orientation of many movement organisations seems also to have occupied the EE/ESD field. One can understand the emphasis on the recycling and 3 Rs policy issue. It is related to the need, both at local and national level, to achieve goals and compromises at the European level, whose organisations promote and fund $\mathrm{EE}$ projects on these issues. Hence, the systematic and relatively voluminous production of teaching materials and the promotion of this thematic area by public organisations of local and central administrations and by waste recycling business companies. What happens is that, besides being limited and approached in a very restrictive, non-transversal view, these two issues are relatively secondary in the panorama of the actual environmental concerns of the population.

The survey presented in this paper and whose results are being analysed was launched after a particularly punishing season, due to forest fires and drought. Despite that, both water pollution and, principally, forest fires did not receive attention by EE promoters. The prevalence and persistence of focus on the ecological question in itself to the detriment of its articulation to civic and citizenship issues are at odds with the need to strengthen an essential feature of the Education for Sustainable Development Decade.

A second feature of EE/ESD in Portugal we have to highlight relates to the target groups of EE initiatives. The weight of students and younger group's points to a certain kind of what one may call infantilisation of EE/ESD, which means an essentially recreational, playful tendency of EE/ESD activities in Portugal. The very difficulty of $\mathrm{EE} / \mathrm{ESD}$ in penetrating scholar curricula is a symptom if this situation. This is also derived from a trend to institutional disarticulation between the ministries involved. After all, we are facing the missed encounter between a fundamentally curricular vision of education issuing from the Ministry of Education and a practice ingenuously but persistently based in the more recreational aspects of EE by the Ministry of Environment. The organisations of this Ministry developed an essentially marginal, non-articulated and non-curricular view of EE. By contrast, the Ministry of Education has verticality sought to insert programmatic elements of the environment and ecology in the curricula, after the European Union guidelines, with no worrying about articulating learning and civic dimensions of environmental issues and its role to citizenship formative dimensions. After an old tradition in Portugal, both ministries pursued their own, parallel tracks, following their own, different registers: the curricular via by the Ministry of Education, the more ingenuous, recreational one by the Ministry of the Environment. 
A third characteristic, which stems from the previous ones, has to do with the very unsustainability of EE/ESD initiatives themselves. This may be found, for example, in difficulties to give continuity to educational programs and project actions. Projects are born, according to most answers to our questionnaire, with objectives of assuring continuity, but reality quickly puts limits to their ambitions. Most of them, as we saw, do not hold for more than three years and, even if it is a momentary portrait of reality, the majority EE projects have begun less than one or two years ago.

A clear factor of this unsustainability has to do with mobilisation of obstacles, mobilisation of civil society actors in general and of the very school community, starting with the difficulty in convincing and involving teachers in EE projects. Be it due to school organisation features and the support of school directors to this kind of educational activities, or be it by pure and simple lack of motivation, a good part of $\mathrm{EE} / \mathrm{ESD}$ promoters complain about the difficulty in gaining professors to the cause of EE. Bearing in mind the conditions of mobility and insecurity in the work of many teachers in public teaching, it is frequent that, with the exit of a certain teacher, EE projects just die by inaction or lack of interest by other teachers.

Closing the circle, what is lacking is the ability to mobilise partners and participants that can, in a gradual, continuing way, give meaning and coherence to the actions and initiatives of EE/ESD.

\section{References}

Almeida, J.F. (2000) Os Portugueses e o Ambiente - I Inquérito Nacional às Representações e Práticas dos Portugueses sobre o Ambiente, Celta, Oeiras.

Almeida, J.F. (2004) Os Portugueses e o Ambiente - II Inquérito Nacional às Representações e Práticas dos Portugueses sobre o Ambiente, Celta, Oeiras.

Beckman, L. (2001) 'Virtue, sustainability and liberal values', in Barry and Wissenburg (Eds.): Sustaining Liberal Democracy: Ecological Challenges and Opportunities, pp.179-91, Palgrave, Basingstoke.

Benavente, A. (1996) A Literacia em Portugal: Resultados de uma Pesquisa Extensiva e Monográfica, Fundação Calouste Gulbenkian, Lisbon.

Binstock, M. (2006) A Survey of National Environmental Education and Education for Sustainable Development Laws and Policies: Lessons for Canada, Canadian Institute for Environmental Law and Policy, Toronto.

Boff, L. (2004) Ecologia: Grito da Terra, Grito dos Pobres, Sextante, Rio de Janeiro.

Jickling, B. and Spork, H. (1998) 'Education for the environment: a critique', Environmental Education Research, Vol. 4, No. 3, pp.309-327.

Martinho, G. (2003) Memórias de 12 anos de Educação Ambiental - 1990/2002, APEA/FCT-UNL, Lisboa.

Schmidt, L. (2005) 'Educação ambiental e educação para o desenvolvimento sustentável: um futuro comum', in Proceedings of Jornadas Pedagógicas de Educação Ambiental, ASPEA, Ericeira.

Schmidt, L. and Lima, A.V. (2005) 'Análise das campanhas contra os fogos florestais', in Plano Nacional de Defesa da Floresta contra Incêndios, APIF, Lisbon.

Schmidt, L., Nave, J.G. and Guerra, J. (2006) 'Who's afraid of local agenda 21? Top-down and bottom-up perspectives on local sustainability', International Journal of Environment and Sustainable Development, Vol. 5, No. 2, pp.181-198.

Stapp, W.B. et al. (1969) 'The concept of environmental education', Journal of Environmental Education, Vol. 1, No. 1, pp.30-31. 
UNESCO (1978) 'The Tbilisi declaration: final report', Intergovernmental Conference on Environmental Education, 14-26 October 1977, organized by UNESCO in cooperation with UNEP, Tbilisi.

WCED (1991) Our Common Future, Portuguese version, Meribérica, Lisbon. 